\title{
Mental health in the time of COVID-19
}

\section{Roberta Heale $\left(1,{ }^{1}\right.$ Jane Wray ${ }^{2}$}

$10.1136 /$ ebnurs-2020-103350

${ }^{1}$ School of Nursing, Laurentian University, Sudbury, Ontario, Canada

${ }^{2}$ Nursing, University of Hull, Hull, UK

Correspondence to:

Dr Roberta Heale, School of Nursing, Laurentian University, Sudbury, ON P3E 2C6, Canada; rheale@laurentian.ca
October is Mental Health Awareness Month and World Mental Health Day takes place on 10 October 2020. This year, the COVID-19 pandemic has added a new dimension to concerns regarding mental health in our communities. Across the globe stories continue to emerge of people's experiences of anxiety, fear and depression due to the uncertainty and stress brought on by the virus. ${ }^{1-3}$ Job losses, financial and housing insecurity, the challenges of working from home, home schooling, restricted access to health and social care services and social isolation coupled with reduced support and contact with family and friends have all impacted people's well-being. There is particular concern about the mental health of healthcare workers during this difficult time.

While most healthcare workers are resilient to the long-term effects of this period of stress and anxiety, there is the added worry about scarce resources, lack of cure or effective treatment options, isolation from family, coping with patient suffering and deaths and the moral and ethical impact of decisions as to who will receive acute care. These factors have significant potential for negative repercussions on the mental health and well-being of healthcare staff. ${ }^{4}$ There have been reports of high levels of stress, depression and even suicides, ${ }^{6}$ and longterm effects include a higher risk for post-traumatic stress disorder or moral injury. ${ }^{5}$

Healthcare organisations need to plan for the inevitable consequence of this pandemic and ensure that resources are in place for their workers. Screening for mental health issues and treatment, including counselling, should be made available. In addition, nurses and other healthcare staff should be encouraged to reflect on their experiences and consider how to implement self-care strategies that will enhance their well-being. This includes staying informed of the current data and information and being aware of the risks to themselves and others while caring for patients with the virus. By monitoring and enacting strategies to reduce stress and develop support systems, staff can minimise longer-term impacts. ${ }^{4}$

Whether organisational support and self-care monitoring have achieved better mental health outcomes for healthcare workers is, as yet, unknown. Research across the globe is underway not only related to the virus itself but also to the mental health consequences of the pandemic. We do not yet know the extent of the issues or how best to support healthcare providers. In order to better understand the issues and to support nurses at this time, evidencebased nursing will focus our social media to mental health issues during the month of October. We will highlight and share relevant resources and information and encourage discussion of the key challenges facing healthcare workers.

During October, we will showcase the experiences of four key groups-patients, nurses, students and informal carers and families. Be sure to log into evidence-based nursing each week for the following blogs:

October 4: Impact of COVID-19 on patient mental health.
October 11: Impact of COVID-19 on nurses' mental health and.

Twitter Chat on Wednesday October 14 at 20:00 UK time.

Oct: 18: Impact of COVID-19 on student nursing.

Oct: 25: Impact of COVID-19 on informal carers and families.

Twitter Roberta Heale @robertaheale and Jane Wray @livinginhope

Funding The authors have not declared a specific grant for this research from any funding agency in the public, commercial or not-for-profit sectors.

Competing interests None declared.

Patient consent for publication Not required.

Provenance and peer review Commissioned; internally peer reviewed.

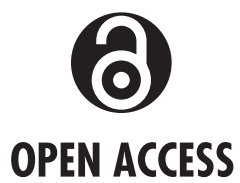

Open access This is an open access article distributed in accordance with the Creative Commons Attribution Non Commercial (CC BY-NC 4.0) license, which permits others to distribute, remix, adapt, build upon this work non-commercially, and license their derivative works on different terms, provided the original work is properly cited, appropriate credit is given, any changes made indicated, and the use is non-commercial. See: http://creativecommons.org/licenses/by-nc/4.0/.

๑ Author(s) (or their employer(s)) 2020. Re-use permitted under CC BY-NC. No commercial re-use. See rights and permissions. Published by BMJ.

ORCID iD

Roberta Heale http://orcid.org/0000-0003-2221-1573

\section{References}

1 World Health Organization. Mental health and Covid 19. Available: https://www.who.int/teams/mental-health-andsubstance-use/covid-19

2 NHS. Mental wellbeing while staying at home. Available: https://www.nhs.uk/oneyou/every-mind-matters/coronaviruscovid-19-staying-at-home-tips/

3 CAMH. Mental health and the COVID-19 pandemic. Available: https://www.camh.ca/en/health-info/mental-health-and-covid-19

4 Pfefferbaum B, North CS. Mental health and the Covid-19 pandemic. N Engl J Med 2020. doi:10.1056/NEJMp2008017. [Epub ahead of print: 13 Apr 2020].

5 Greenberg N, Docherty M, Gnanapragasam S, et al. Managing mental health challenges faced by healthcare workers during covid-19 pandemic. BMJ 2020;368:m1211.

6 Knoll C, Watkins A, Rothfeld M. 'I couldn't do anything': The virus and and E.R. doctor's suicide. New York Times, 2020. Available: https://nyti.ms/3egTT12 